\title{
How COVID-19 Brought Indian Wedding Industry to a Halt?
}

\author{
Ravi Kumar Arya, Ritik Ranjan Gupta, Jatin Kumar, Tanay Shubham, Ravi Dugh
}

\begin{abstract}
COVID-19 has spread all over the world. Starting from China, it has reached mostly all countries of the world. It has affected major industries and some industries are at the brink of total collapse. Indian wedding industry was one of the most progressive industry in the world but COVID-19 has brought it to its heels. Lockdown due to COVID-19 has restricted major public functions and wedding industry has to follow these guidelines too. In this research, we take exhaustive study showing social and economic impacts of COVID-19 on Indian wedding industry.
\end{abstract}

Keywords: Indian Wedding, Indian Marriage, Indian Market, Wedding Market

\section{INTRODUCTION}

$\mathrm{N}_{\text {ovember and December are the busiest months for }}$ weddings in India. But due to COVID-19, the wedding industry has taken a toll as most other industries in the world did. The Indian wedding industry is one of the largest in the world and is a $\$ 50$ billion industry [1]. It is also growing at a rate of $25 \%-30 \%$ annually. It is the second-largest wedding market after the USA, which is at \$70 Billion [2]. Every year 10 million marriages take place in India [3]. But this year has been different. COVID-19 has affected the marriage industry adversely. The wedding industry has been hit hard due to the government's COVID-19 restrictions to stop the spread of coronavirus disease. Currently, India has 9,392,919 total number of cases and 136, 696 people have died until now due to this pandemic. Every day these numbers are rising and putting extra pressure on different businesses. The wedding industry has many interlinked industries, and all are feeling the pinch. Caterers, designers, banquet/tent house owners, makeup artists, wedding vendors, or planners are all impacted by the sudden change of circumstances this year. Most of the weddings are either getting cancelled or delayed. The remaining ones are not attracting the crowds that they typically did due to the government guidelines. In these scenarios, these different businesses are collapsing badly. To understand the effects of COVID-19 on these businesses, we

Revised Manuscript Received on January 15, 2021.

* Correspondence Author

Ravi Kumar Arya*, Electrical and Communication, National Institute of Technology Delhi, New Delhi, India. Email: raviarya@nitdelhi.ac.in

Ritik Ranjan Gupta, Electrical and Electronics, National Institute of Technology Delhi, New Delhi, India. Email: 181230040@nitdelhi.ac.in

Jatin Kumar, Electrical and Communication, National Institute of Technology Delhi, New Delhi, India. Email: jatin9562@gmail.com

Tanay Shubham, Electrical and Electronics, National Institute of Technology Delhi, New Delhi, India. Email: 171230004@nitdelhi.ac.in

Ravi Dugh, Goergen Institute Data Science, The University of Rochester, NY, USA. Email: ravi.dugh@gmail.com

(c) The Authors. Published by Blue Eyes Intelligence Engineering and Sciences Publication (BEIESP). This is an open access article under the CC BY-NC-ND license (http://creativecommons.org/licenses/by-nc-nd/4.0/) have an exhaustive study of different aspects of these interlinked businesses and investigate their social and economic impacts. In the end, we conclude our research by proposing some mitigation techniques that can help to save these businesses.

Following are the current rules to be followed for attending a wedding in India due to COVID-19 restrictions [4]:

- People should adhere to social distancing norms during the entire function.

- They should wear a mask during the ceremony.

- The guests should use hand-sanitizer.

- Ceremonies should be kept as short as possible.

- Not more than 50 people can attend a wedding.

- No drink or food is consumed during the ceremony until absolutely necessary.

- Many states set their own rules, including the number of guests allowed in a wedding function.

Because of so many rules and fear of COVID-19, people are avoiding weddings this year, or they are getting their weddings done in the simplest way also if they can do it without any function and guests. As it is common in Indian wedding functions, many people gather to celebrate it. But due to the safety, all have to follow physical distance from each other, which is not possible in the crowd, so most of the wedding functions are adversely affected or cancelled.

Indian weddings are all about extravaganza and if people get so uncertain about the future, every part of this industry will bleed and is bleeding currently. A typical wedding consists of many different expenses from different functions. Wedding cost mostly depends upon the socio-economic status of a family. Parents start planning for their child's marriage years in advance. A person typically spends one-fifth of their total accumulated lifetime wealth on wedding ceremonies [5]. Typical Indian wedding costs INR 5 lakh to INR 5 crore.

Major factors that decide overall wedding cost are:

- Number of guests

- Number of functions in a wedding

- Traditional activities

- Venue location, banquet hall decorations

- Food expenses

Some people are also realizing that money management is critical for survival [6] through this pandemic time and it is important to take care of extra or unwanted expenses. So, we will see the change in marriage expenses during COVID-19 as people are trying to keep their savings intact and try to spend the minimum to face an uncertain future.

Published By:

Blue Eyes Intelligence Engineering and Sciences Publication

(C) Copyright: All rights reserved.

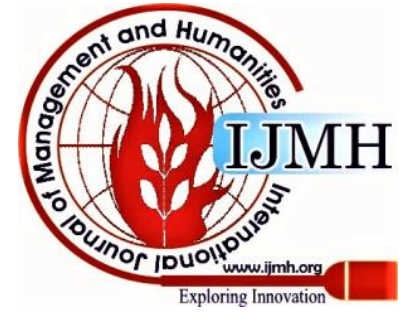




\section{INDIAN WEDDING INDUSTRY}

\section{A. Online Wedding Website/ Bureau}

In Fig. 1, we see matrimony.com Limited share price change [7]. We can see share prices started decreasing at the inception of COVID-19, and it was too low when COVID-19 was on the peak (March 20, April 20, May 20), then these prices started to increase as the weddings resumed. To cope with a sudden change in circumstances, online matrimonial websites/bureaus came with new offers and deals for their customers and also introduced new features on their app/website like online chatting/video calling features etc. Even they offered deals during the lockdown periods such as free premium membership. And that's the reason for the considerable increase in their share prices once people started to realize that the COVID-19 situation will stay for long.

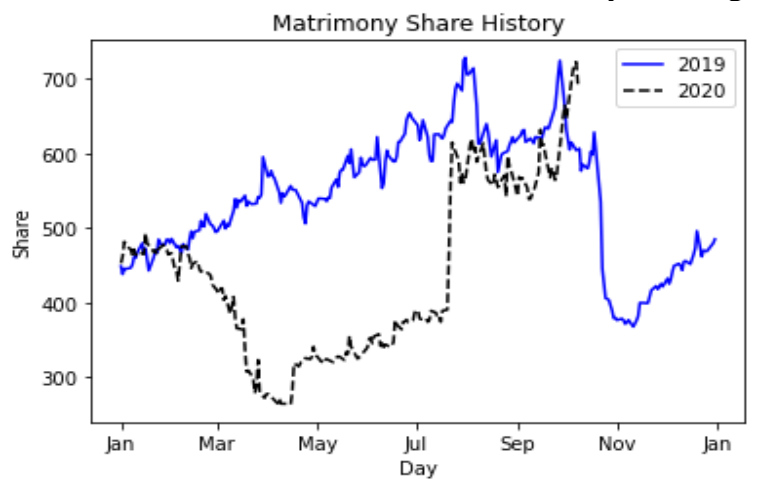

Fig. 1. Matrimony.com Ltd. Share Price.

According to The New York Times [8], there are over 1500 matrimony websites in India. According to a survey, traffic on matchmaking apps and sites increased during the lockdown. Jeevansaathi.com saw a 30\% growth in new user acquisitions year-on-year during the period. Shaadi.com witnessed a traffic surge of $15-20 \%$ on its platform, compared to the pre-COVID period, while BharatMatrimony.com also reported a 30\% increase in registrations. These are the top 3 matrimonial websites in India. The time spent on these platforms increased too. Jeevansaathi.com has seen a $20 \%$ increase in time spent on its platform, and engagement on Shaadi.com is up by $25 \%$. But with strict social distancing norms in place during this time, these numbers may mean little. India's matchmaking market is valued at $\$ 184$ million [9] and is expected to grow at a compound annual growth rate (CAGR) of $10 \%$ to reach $\$ 269$ million by 2024. The website estimates that the market has about 8.2 million users in the country currently. As from the above data, we can say that because of the pandemic the population is more shifting towards the online facilities [10].

\section{B. Jewellery Industry}

"If India sneezes, the gold industry will catch a cold," says Ajay Mitra of the World Gold Council [11]. With the current situation, gold and related Jewellery industry have certainly caught a cold. India, the world's second-biggest gold consumer, experienced the lowest sales of gold in the past 25 years. Total purchases are estimated to plummet 30\% in 2020 from the 690 tons last year. That would make it the smallest annual purchase since the 477 tons bought in 1995, according to data compiled by Bloomberg based on World Gold Council reports. As in India, Jewellery is sold mostly on occasions such as weddings. As COVID-19 has hit the country in 2020 almost all the wedding functions got cancelled or postponed and the demand for Jewellery has gone down. It also affected the price of gold and silver [12] as shown in Fig. 2.
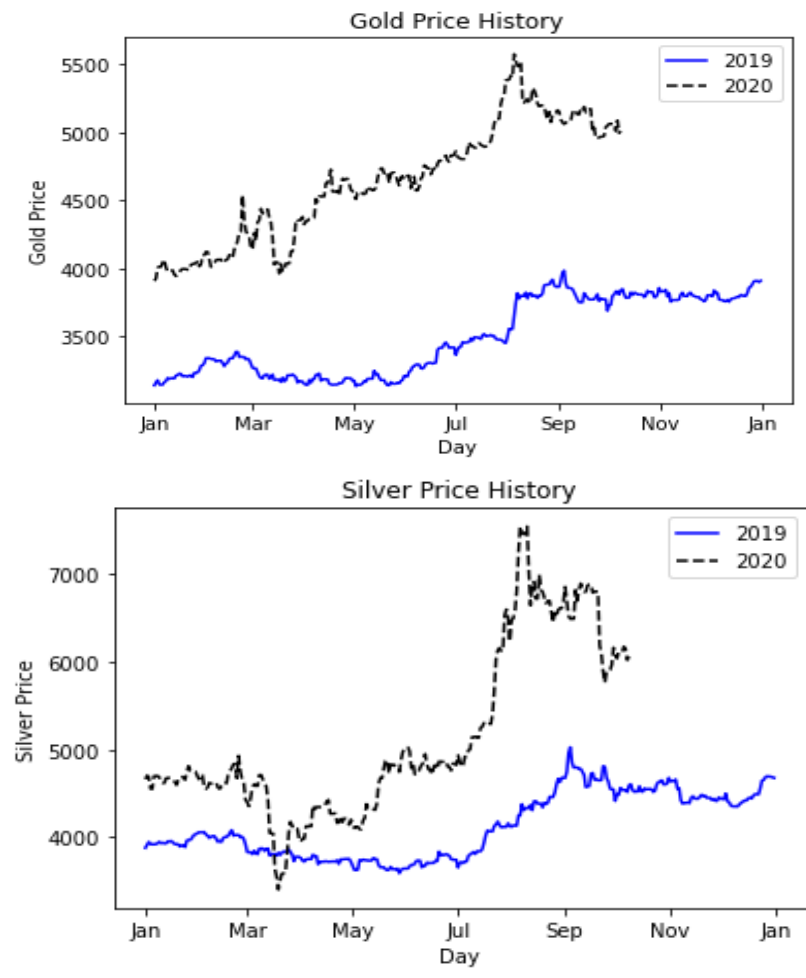

Fig. 3. Share price of Titan Corporation.

\section{Wedding Photography}

These days wedding photography not only includes photography during the wedding but pre-wedding shoots are also gaining traction. Due to the low count of wedding guests, people are also avoiding expenses on grand photography. Typical wedding shoots can cost INR 15, 000 to INR 100,000 [14]. Affording even that much money is getting difficult for families where they have lost jobs.i

\section{Destination Wedding}

There is no doubt that India has many beautiful locations but many people choose a destination wedding outside India to make it a memorable moment [15]. Due to COVID-19, the aviation sector has limited flight traffic. People are avoiding unnecessary travel and government restrictions are also keeping the air travel under control. People are also wary of changing scenarios as new studies are finding COVID-19 to be air-borne [16]. Different countries are implementing different lockdown conditions. Due to all these reasons, going for a destination wedding does not look like a healthy choice in these difficult times. All this has adversely impacted this sector economically and it will take some time to bring this earlier blooming sector back to its earlier glory.

\section{E. Marriage Banquets and Tent House}

According to the Hindustan Times, there are around 500 banquets and 5700 tent houses in Delhi [17]. Majority of banquets have 2-3 halls with a capacity of 350-500 guests each, but according to the government guidelines passed in Unlock 4 that from September 21, 2020 gathering of up to 100 people is allowed [18], and using these banquets at such low attendance is incurring big losses to owners of such places.

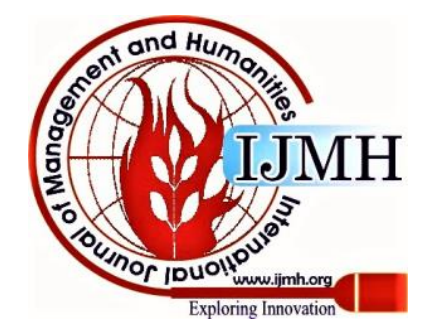


And because of changing of rules in every unlock guidance, creating confusion among people which led to the cancellation of pre-booking which also became a blocker for the banquet's owners.

India hosts over 10 million weddings every year which gives employment to thousands of people as it requires lots of manpower and venues to host these events, but due to current situation it created a large number of employment and a huge loss to banquet's owners as they have to spend money on maintenance, electricity and staffs despite zero bookings. These constant expenses with no future income led owners of such places to start firing people from their jobs. Now, while the banquet owners have started wedding bookings, tent house owners are still facing problems with their business. Most of the tents are used for big weddings and other events that are held at parks and open areas. But with current restrictions, such activities in parks and open areas are not allowed and are affecting tent owners badly.

\section{F. Band Artists and Caterers}

The COVID-19 pandemic fear and the need to maintain social distancing have forced people to postpone their intimate affairs instead of their big fat events, which has These industries are run only by manpower and because of no people. Most of the band artists and caterers come from the village to big cities but due to current situation, many are forced to seek another source of livelihood or to go back to cities. The pandemic also created a phobia of not getting jobs in future as most of the small workers are afraid that now marriage won't happen the way they used to be. Most of the band groups have taken loans from a bank or private authorities to get instruments and band dresses which are lying useless at present, but they have to pay back the loan despite any income. Many caterers have taken Godowns on rent for storage which is also becoming a burden on them.

\section{G. Marriage Retail Shopping}

After the lockdown started, the offline retail market experienced a huge downfall. According to a KPMG report of 2018, the big Indian wedding market is often considered recession-proof [19]. But due to the pandemic, this huge market went down. As during the lockdown period, even some marriage functions were going on either online or in-house, the shops were closed which resulted in zero sale of wedding items. As the lockdown was lifted and shops started to open, there are still almost zero sale in the market due to changed wedding scenarios. People are preferring not to go to market due to COVID-19 phobia and they are trying to do online shopping as much as possible which is also affecting small retailers with a huge loss. After the unlock started the shopkeepers started offering heavy discounts to clear their stocks and get some money as many of them filled their shops with stock just before COVID-19 spread by borrowing money and they have to pay them back which is a challenge for them in current situations.

\section{FACTORS EFFECTING WEDDING AFTER COVID-19}

In this section, we list different factors affecting the weddings after COVID-19 spread. Most of the weddings are wedding ceremonies or some couples to opt for small affected businesses of bands and caterers in the country. bookings, it created huge unemployment among these the village as they don't have enough money to survive in the

getting postponed or even get cancelled due to change in people's situation after COVID-19.

\section{A. Employment}

As the COVID-19 hit, it led to an economic crisis in the country. Many lost their jobs and many went into the huge loss which adversely effected the employment rate of the country. During the lockdown period (April, 2020 - May, 2020) the unemployment rate went to peak in just one month [20] as shown in Fig. 4. As many people started losing their jobs, it also created uncertainty about their marriage. Due to no job, people started cancelling the wedding or postponed them.

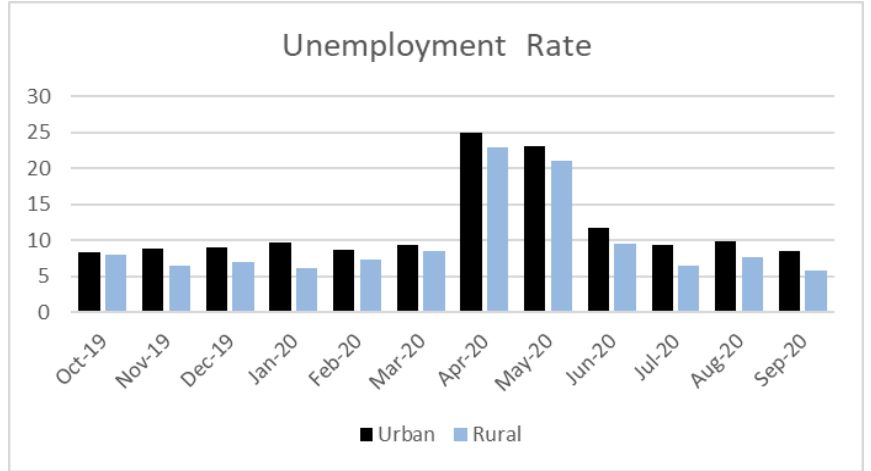

Fig. 4. Unemployment rate in India.

\section{B. Government Rules and Regulation}

As the unlock started with tons of rules and regulations by the government, it becomes very difficult to have a function as it used to be before the COVID-19 spread. In India, wedding is the dream of the parents, they always plan to do as much as possible in their children's wedding function. India has a tradition of inviting family members and close ones to their weddings and celebrate with all. But due to these rules and regulations it is almost impossible to have a function like before. So, because of so many ever-changing rules and fear of COVID-19, most of the people are avoiding weddings this year or they are getting their weddings done in the simplest way they can without any function and guests.

\section{Savings}

In India, most of the parents save a part of their hard-earned money for their children and their marriage. But during the lockdown, many families are forced to spend their savings to fulfil their daily requirement as the market was closed so there was no source of income which created a huge burden on parents and families.

\section{Patient Phobia}

After the COVID-19 spread, the people's mindset has changed too as everyone is treating each other as a source of virus because of their own safety. This mindset is also followed in weddings. Recently, there are frequent news of virus spread in wedding functions. In one of the wedding, groom died just after two days of wedding by COVID-19 and 95 guests also got COVID-19 positive [21], further creating phobia for people that weddings are spreading coronavirus and can be deadly to attend. Apart from the industry collapse, there are also other social and economic factors to be considered.

Published By: 


\section{How COVID-19 Brought Indian Wedding Industry to a Halt?}

Many people have lost jobs and it is getting difficult to get new jobs. This has also lowered the chances for young people to get married. Most parents of the bride want their future son-in-law to have future job security as it gives better financial stability. Losing a job in such trying times is also bringing the marriage count low. For many parents, savings have almost exhausted; therefore, they will not be able to afford weddings of their children for some time.

\section{E. India's GDP}

Almost every industry got affected due to COVID-19 which led to huge drop in the India's GDP as shown in Fig. 5. There was a huge drop in the first quarter of 2020 when the lockdown was implemented in the country.

Table- I: GDP rate of past 5 Years

\begin{tabular}{|l|l|l|l|l|l|}
\hline \multirow{2}{*}{ Quarter } & \multicolumn{5}{|c|}{ Year } \\
\cline { 2 - 6 } & $\mathbf{2 0 1 6 - 1 7}$ & $\mathbf{2 0 1 7 - 1 8}$ & $\mathbf{2 0 1 8 - 1 9}$ & $\mathbf{2 0 1 9 - 2 0}$ & $\mathbf{2 0 2 0 - 2 1}$ \\
\hline Q1 & 8.68 & 5.78 & 7.10 & 5.25 & -23.92 \\
\hline Q2 & 9.67 & 6.47 & 6.20 & 4.42 & \\
\hline Q3 & 8.58 & 7.64 & 5.59 & 4.08 & \\
\hline Q4 & 6.29 & 8.18 & 5.67 & 3.09 & \\
\hline
\end{tabular}

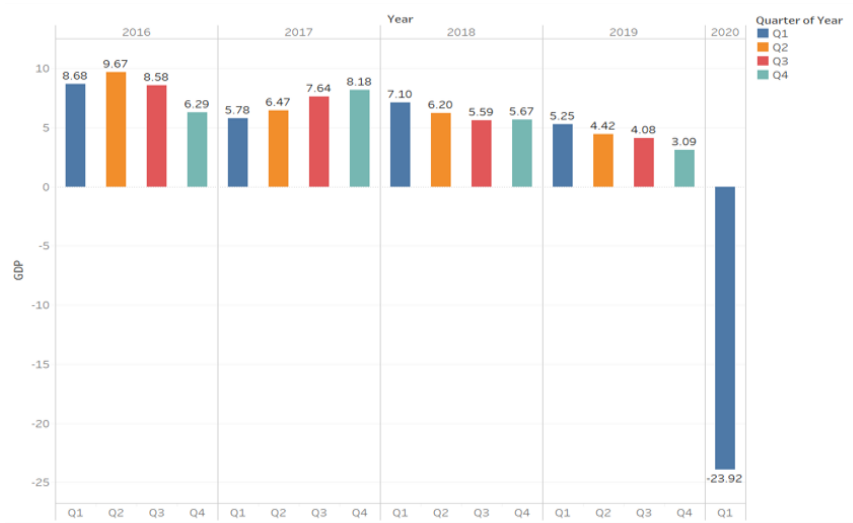

Fig. 5. India GDP Trend.

On further investigation, we can come to the conclusion that somehow the different sectors of the GDP are directly related to the marriage industry. In Fig. 6, we see the share of each sector effecting the GDP. [22]

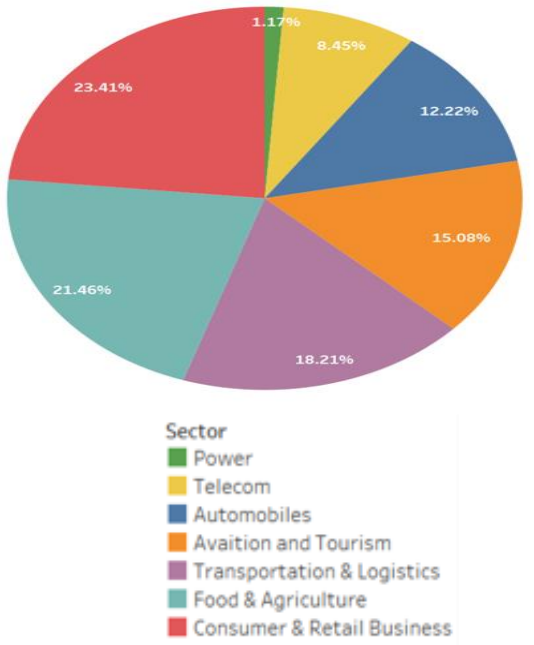

Retrieval Number:100.1/ijmh.E1210015521

DOI:10.35940/ijmh.E1210.015521

Journal Website: www.ijmh.org

\section{IS ONLINE WEDDING THE NEXT FUTURE?}

There are many ways in which technology can be used today for online weddings. Dance performances can be recorded and played during the sangeet (music) ceremony. The wedding can be broadcast on online live video platforms. Guests can dress up in finery and participate through video calls from their drawing rooms. And when the time comes for the feast, delivery services can deliver the exact same menu to each of the invited guests. Imagine having a small wedding in a truly blissful location with a few people in attendance and then hundreds of others participating through 3D virtual reality goggles. Drones can deliver amazing camera angles and swoop around the beautiful landscape. Flowers, food, scents - all the other wedding accoutrements can be brought to those participating remotely through a wedding planning service. The money saved on travel, hospitality, and transportation can be utilized to ensure a truly memorable in-home wedding experience. Even using augmented reality, the guests can be virtually present at the wedding while sitting in their drawing rooms. Not only that, people can have wedding anniversaries to just get the feel of the real weddings once the COVID-19 vaccine comes and we feel much safer.

\section{CONCLUSION}

The key question is if the wedding industry is impacted, then what is the future of the wedding industry in India? From the above sections, we have shown the new normal that the industry is witnessing. These changes will stay for some time and related industries will have to change accordingly. We will also see a digital wedding taking away bigger pie in coming times as it adheres better to these new times. Even if it is not fully digital, we will definitely see significantly cheaper weddings in India. Businesses like online matchmaking will have new opportunities to make money. We will also see a major part of the existing workforce changing careers or using new second career to feed themselves as it will be difficult for such a large workforce to learn new skills in such a short time with so many restrictions in place. It is going to be a difficult time for the Indian wedding industry and only time will tell how we cope with this new normal.

\section{REFERENCES}

1. The recession-proof Big Fast Indian Wedding just got more corporatized. cnbctv18.com. Accessed October 04, 2020 https://www.cnbctv18.com/retail/the-recession-proof-big-fast-indianwedding-just-got-more-corporatised-1012991.htm

2. Pandit, Virendra. "Big fat Indian wedding market has foreign 'suitor' Zankyou lining up", accessed October 5, 2020 https://www.thehindubusinessline.com/news/national/big-fat-indianwedding-market-has-foreign-suitor-zankyou-lining-up/article9622383 .ece

3. India's love affair with gold, CBS News, February 13, 2012 , https://web.archive.org/web/20120213212435/http://www.cbsnews.co m/8301-18560_162-57376057/indias-love-affair-with-gold/

4. Getting married during the coronavirus outbreak? Check state-wise wedding rules here, accessed on October 5, 2020, https://www.timesnownews.com/india/article/getting-married-duringthe-coronavirus-outbreak-check-state-wise-wedding-rules-here/62186 $\underline{8}$ 
5. How much does a typical upper-middle-class wedding cost? accessed October 2020 https://www.aegonlife.com/insurance-investment-knowledge/how-mu ch-does-a-typical-upper-middle-class-wedding-cost/

6. Spend cautiously to sail through the coronavirus pandemic, accessed on October $\quad 5$, 2020, https://m.economictimes.com/wealth/spend/spend-cautiously-to-sail-t hrough-the-coronavirus pandemic/articleshow/78329758.cms

7. NSE, matrimony Com Limited https://www.nseindia.com/get-quotes/equity?symbol=MATRIMONY

8. Websites in India Put a Bit of Choice Into Arranged Marriage, accessed on October 5, 2020

9. https://www.nytimes.com/2015/04/26/world/asia/india-arranged-marr iages-matrimonial-websites.html

10. How matrimonial apps have turned to organize weddings during the pandemic, , accessed on October 5, 2020

11. https://www.financialexpress.com/brandwagon/how-matrimonial-app s-have-turned-to-organising-weddings-during-the-pandemic/1999113/

12. https://www.financialexpress.com/brandwagon/how-matrimonial-app s-have-turned-to-organising-weddings-during-the-pandemic/1999113/

13. Precious metal: India's love affair with gold, CBS News, accessed on Feb.

13 ,

2012 https://web.archive.org/web/20120213212435/http://www.cbsnews.co m/8301-18560_162-57376057/indias-love-affair-with-gold/

14. India braces for lowest gold sales in 25 years as virus hits, accessed on October

2020

https://economictimes.indiatimes.com/markets/commodities/news/ind ia-braces-for-lowest-gold-sales-in-25-years-as-virus-hits/articleshow/ 74795271.cms

15. NSE,TITAN

https://www.nseindia.com/get-quotes/equity?symbol=TITAN

16. "One wedding photo shoot. Make it viral please!" accessed October 4, 2020

https://timesofindia.indiatimes.com/life-style/spotlight/one-wedding-p hoto-shoot-make-it-viral-please/articleshow/70710938.cms

17. "Indian celebs who married outside India" accessed October 4, 2020 https://www.orissapost.com/indian-celebs-who-married-outside-india/

18. Morawska, Lidia, and Donald K. Milton. "It is time to address the airborne transmission of COVID-19." Clin Infect Dis 6 (2020) ciaa939.

19. "Covid-19 shadow over big, fat weddings in Delhi." https://www.hindustantimes.com/delhi-news/covid-19-shadow-over-b ig-fat-weddings-in-delhi/story-O5NucA9dhDoYbJSvIO9ipI.html

20. "Govt allows sports gathering of up to 100 people from September 21"

21. http://timesofindia.indiatimes.com/articleshow/77826097.cms

22. "The recession-proof Big Fast Indian Wedding" https://www.cnbctv18.com/retail/the-recession-proof-big-fast-indianwedding-just-got-more-corporatised-1012991.htm

23. CMIE, https://unemploymentinindia.cmie.com/

24. "Bihar: Groom dead, 95 guests test Covid-19 positive" https://timesofindia.indiatimes.com/city/patna/bihar-groom-dead-95-g uests-test-covid-19-positive/articleshow/76706537.cms

25. "THE IMPACT OF COVID 19 IN INDIAN ECONOMY - AN EMPIRICAL-STUDY",

http://www.iaeme.com/MasterAdmin/Journal_uploads/IJEET/VOLU ME_11_ISSUE_3/IJEET_11_03_023.pdf

\section{AUTHORS PROFILE}

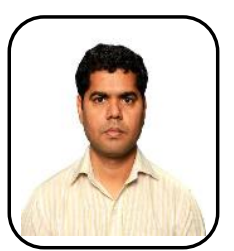

Ravi Kumar Arya received the Ph.D. degree in Electrical Engineering from the Pennsylvania State University, USA in 2017. In 2019, he joined NIT Delhi, India, where he is currently an Assistant Professor in the Department of Electronics and Communication Engineering. In 2017, he worked with Isotropic Systems, MD, USA as RF Optical Design Engineer where he developed various antennas for satellite communication systems, wrote various analysis tools for lens and array design, implemented and managed Amazon Web Services (AWS) computer resources for the company. He received his M. Tech in RF and Microwave Engineering from Indian Institute of Technology, Kharagpur, India in 2006 and B. E. from Delhi Technological University, Delhi, India in 2003 respectively. After completing B. E., he worked with Electronics Corporation of India Limited, India for 6 months and then with Centre for Development of Telematics (C-DOT), India from 2006 to 2010. He has published several technical papers in highly ranked journals and refereed conference proceedings, including three book chapters. His research interests include RF circuit design, antenna design, lens design and the analysis of frequency-selective surfaces

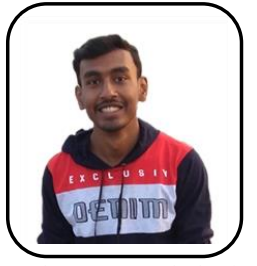

Ritik Ranjan Gupta is pursuing his under graduation in Electrical and Electronics Engineering from National Institute of Technology and will complete it in 2022. He has done projects in Data Science and Analytics. His Major area of Interest is Management and Engineering. He has participated in International conference conducted by NIT Jalandhar. His research interests include Data Science, Statistical Modelling, Data Analysis. He has done various internships in the field of Data Science and Web Development. He is also a Social worker, Volunteered in Many NGOs and Social Groups.

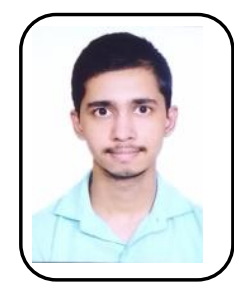

Jatin Kumar is a final year student in Electronics and Communication branch at National Institute of Technology, Delhi. He has done several projects in machine learning and data science like Covid-19 face mask detection app, Hindi hand written text analyzer, housing price predicting website, sports celebrity classifier webpage, sales insights generating Power BI dashboard.

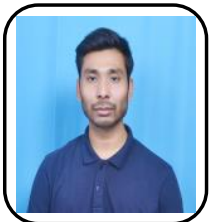

Tanay Shubham is a under graduate student Electrical and Electronics Engineering, National Institute of technology Delhi. His minor project in $7^{\text {th }}$ semester $\left(4^{\text {th }}\right.$ year) was on skin cancer detection using computer vision. His summer internship in June 2019 in National Hydro Power Corporation was on hydropower generation also in June 2020 he did his summe internship on smart grid requirement in Indian power system under Dr. Ami Kumar Singh, Assistant professor, NIT Delhi.

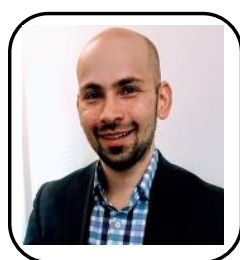

Ravi Dugh has over 15 years of diverse experience and has worked in various industries, including energy, telecom, professional services, and building materials. Ravi has worked with many leading companies, including Halliburton and Lafarge Holcim.

Ravi has a Bachelor of Engineering from Delhi Technological University (formerly Delhi College of Engineering, University of Delhi) in Electronics and Communications. Ravi also has a Master of Business Administration (MBA) degree from the Rotman School of Management, University of Toronto. Recently, he earned a graduate-level certification in Financial Technology from Seneca College. Ravi is currently pursuing his Master of Science degree in Data Science at the University of Rochester and gaining skills in computational methods to offer innovative solutions to both engineering and management problems. Ravi has a passion for business, technology, and research. His research interests include Digital Transformation, Data Science for Business, Strategy \& Innovation, Artificial Intelligence, Technology Management.

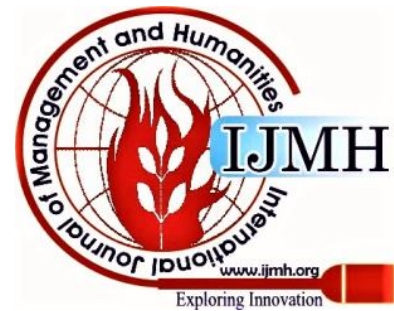

